\title{
Assessment of Soil Fertility Status in the Jurisdiction of Sugar Factory
}

\author{
Shriganesh Ramkrishna Shelke ${ }^{1 *}$, Pramod Achyutrao Gayke², Ashok Laxman Pharande ${ }^{3}$ \\ ${ }^{1}$ Assistant Professor, Department of Soil Science and Agril. Chemistry, MPKV, Rahuri, Maharashtra, India \\ ${ }^{2}$ Post Graduate Student, Department of Soil Science and Agril. Chemistry, MPKV, Rahuri, Maharashtra, India \\ ${ }^{3}$ Dean (F/A) \& Director of Instructions, Mahatma Phule Krishi Vidyapeeth, Rahuri, Maharashtra, India
}

\begin{abstract}
*Address for Correspondence: Dr. Shriganesh Ramkrishna Shelke, Assistant Professor, Department of Soil Science and Agricultural Chemistry, Post Graduate Institute, Mahatma Phule Krishi Vidyapeeth, Rahuri, Ahmednagar (M.S), India E-mail: shelke shriganesh@rediffmail.com
\end{abstract}

Received: 03 Mar 2021/ Revised: 07 Jul 2021/ Accepted: 24 Dec 2021

\begin{abstract}
Background: The high yielding varieties and intensive cropping together with the shift towards the use of high NPK fertilizers has caused the decline in the level of micronutrients in soils below normal at which productivity of crops cannot be sustained. Methods: The GPS based104 soil samples were collected and analyzed for fertility status and nutrient indices in 2017-18.

Results: The $\mathrm{pH}$ and EC of soils of sugar factory varied from 7.78 to 8.73 and 0.17 to $1.33 \mathrm{dSm}^{-1}$, respectively. The organic carbon and calcium carbonate content in soils also varied from 0.21 to $0.82 \%$ and 5.25 to $15.75 \%$, respectively. The available nitrogen, phosphorus and potassium content in soils were ranged from 137.90 to $310.40,6.37$ to 27.12 , and 257.60 to $763.20 \mathrm{~kg}^{-1}$ respectively. The soil fertility status recorded from very low to moderate in available nitrogen, from very low to moderately high available phosphorus and high to very high available potassium. The available boron ranged from 0.05 to $0.40 \mathrm{mg} \mathrm{kg}^{-1}$. The iron, manganese, zinc and copper content ranged from 2.00 to $6.08,1.22$ to $3.87,0.24$ to 1.86 and 1.09 to $4.42 \mathrm{mg} \mathrm{kg}^{-1}$, respectively. The soils of the sugar factory are sufficient in available copper.

Conclusion: The $69.23 \%, 2.88 \%$ and $65.38 \%$ samples were deficient in available iron, manganese and zinc, respectively. The soil fertility status of sugar factory was assessed to be low in available nitrogen, medium in available phosphorus and high in available potassium respectively.
\end{abstract}

Key-words: Fertility, Global positioning system, Micronutrients, Nutrient status, Salinity

\section{INTRODUCTION}

Maharashtra is one of the most industrialized states in India. Many industries are situated all over Maharashtra. The industries play an important role in the development of the Indian economy and employment generation. However, industrial development sometimes creates an adverse effect on the human population, water, air, soil and environment. Sugar industries play an important role in the Indian economy. Although the sugar industry creates ecological problems associated with it such as water and soil pollution.

\section{How to cite this article}

Shelke SR, GaykePA, Pharande AL. Assessment of Soil Fertility Status in the Jurisdiction of Sugar Factory. SSR Inst. Int. J. Life Sci., 2022; 8(1): 2962-2968.

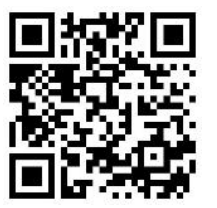

Access this article online https://iijls.com/
The effluent coming out from the industry percolates through the subsoil and reaches the groundwater table forming a contaminated pool. This contaminates the natural groundwater quality, by the accumulation of $\mathrm{Zn}$, $\mathrm{Cu}, \mathrm{Pb}$ and $\mathrm{Cd}$ in soils ${ }^{[1]}$.

The life-supporting systems of a country and the socioeconomic development of its people depend on the soils. More than ever before, renewed attention is being given to soils due to rapidly declining land area for agriculture, declining soil fertility and increasing soil degradation, land use policies and irrational and imbalanced use of inputs ${ }^{[2]}$. Thus soils of Maharashtra State are categorized as poor in fertility and vary widely in genetic, morphological, physical, chemical and biological characteristics ${ }^{[3]}$.

The high yielding varieties and intensive cropping together with the shift towards the use of high NPK fertilizer have caused decline in the level of 
micronutrients in soils below normal at which productivity of crops cannot be sustained. The deficiency of micronutrients has become major constraint for the productivity and sustainability of soils ${ }^{[1]}$.

The GPS is an advanced tool for studying site-specific nutrient management that can be efficiently used for monitoring soil fertility changes. The geo-referenced nutrient status of soils in the jurisdiction of the sugar factory, Kopargaon would be useful for advocating balanced fertilization to crops ${ }^{[3]}$.

\section{MATERIALS AND METHODS}

Place of the study- The present investigation entitled, "Assessment of soil fertility status in the jurisdiction of Kopargaonsugar factory, "at Karmaveer Shankarrao Kale Sahakari Sakhar Karkhana Ltd., Kolpewadi, Kopargaon, Tal. Kopargaon, Dist. Ahmednagar was carried out during 2017-2018.

The Karmaveer Shankarrao Kale Sahakari Sakhar Karkhana Ltd., Kopargaon is located in west of Kopargaon Tehshil. The Kopargaon Tehsil is located in North of Ahmednagar District and West side of Nashik. It is located between latitude ( $\left.19^{\circ} 54^{\prime} 616^{\prime \prime}-19^{\circ} 51^{\prime} 734^{\prime \prime}\right)$ and longitudes ( $\left.74^{\circ} 19^{\prime} 091^{\prime \prime}-74^{\circ} 22^{\prime} 998^{\prime \prime}\right)$. Soils of Karmaveer Shankarrao Kale Sahakari Sakhar Karkhana Ltd, Kopargaon is derived from the igneous rocks viz. Basalt (Deccan trap) which is basic in nature containing mainly feldspars, augite and small amount of titani ferrous magnetite mineral. In the vesicular rocks the any of daloidal cavities are filled with mineral like zeolite and quartz. The climate is usually hot and potential evapotranspiration (PET) is far excess of the precipitation and is classified as semi-arid tropical. Tehsil Kopargaon experience a hot spell from the month of March and May, with rains from June to September. The mean annual maximum and minimum temperatures were ranged from $32.9^{\circ} \mathrm{C}$ to $18.8^{\circ} \mathrm{C}$. The annual rainfall of Kolpewadi village is $517.8 \mathrm{~mm}$.

Methodology- The GPS based soil samples from jurisdiction of Karmveer Shankarrao Kale Sahakari Sakhar Karkhana Ltd., Kopargaon, Dist. Ahmednagar were collected by adopting the standard method of soil sample collections. The following points were taken into consideration while collecting the soil samples for their fertility evaluation. Total 104 soil samples were collected on GPS based. Record of surveyed fields, latitude, and longitude were maintained. The data on crops and use of fertilizers and manures were also recorded. The soil samples from selected site were collected by using wooden stick to avoid iron contamination. Some samples (17) are selected for saturation paste analysis on their physical appearance i.e. white crust on the soil surface, waterlogged soil.

In the laboratory, the samples were air-dried and sieved with a $2 \mathrm{~mm}$ screen, and subjected to physical and chemical analyses following standard analytical procedures. The soil reaction $(\mathrm{pH}$ of $1: 2.5)$ was determined by potentiometric ${ }^{[4]}$. Electrical conductivity (EC) of soil extract was determined using a Conductometric ${ }^{[4]}$. Organic carbon was determined by wet oxidation method ${ }^{[5]}$. Calcium carbonate was determined by Acid neutralization ${ }^{[6]}$. Available $\mathrm{N}$ was extracted with Alkaline permanganate ${ }^{[7]}$, available $P$ was extracted with $0.5 \mathrm{M} \mathrm{NaHCO}$ solution $(8.5 \mathrm{pH}){ }^{[8]}$ and available $\mathrm{K}$ was determined by extraction of soil with neutral normal ammonium acetate ${ }^{[4]}$. For determination of DTPA micronutrients ( $\mathrm{Fe}, \mathrm{Mn}, \mathrm{Zn}$ and $\mathrm{Cu}$ ), soils were extracted with DTPA reagent ${ }^{[9]}$ and were determined with the help of atomic absorption spectrophotometer. Available $B$ was determined by using Azomethin- $\mathrm{H}$ method $^{[10]}$.

\section{RESULTS}

The soil $\mathrm{pH}$ was determined and data obtained are presented in Table 1 . The $\mathrm{pH}$ of the soils was ranged from 7.78 to 8.73 with mean of 8.29 . Among the 104 soil samples tested, $6.73 \%$ soils were slightly alkaline and the remaining $93.27 \%$ of soils were moderately alkaline. The highest soil $\mathrm{pH}$ (strongly alkaline) was 8.73 (19-51'.734"N-74 $19^{\circ} .923^{\prime \prime}$ E) and the lowest (slight alkaline) was $7.78\left(19^{\circ} 53^{\prime} .146^{\prime \prime N}-74^{\circ} 21^{\prime} .650^{\prime \prime} \mathrm{E}\right)$. The data electrical conductivity of soils is presented in Table 1 . The EC of soil samples collected were ranged from 0.17 to $1.33 \mathrm{dSm}^{-1}$ with the mean of $0.39 \mathrm{dSm}^{-1}$. The highest soil EC was $1.33 \mathrm{dSm}^{-1}\left(19^{\circ} 53^{\prime} .538^{\prime \prime} \mathrm{N}-74^{\circ} 21^{\prime} .696^{\prime \prime} \mathrm{E}\right)$ and the lowest was $0.17 \mathrm{dSm}^{-1}\left(19^{\circ} 53^{\prime} .058 \mathrm{~N}-74^{\circ} 20.211 \mathrm{E}\right)$. The data in respect to organic carbon content in soils of the jurisdiction of sugar factory are presented in Table 1 . The organic carbon content in soils was ranged from 0.21 to $0.82 \%$ with a mean of $0.50 \%$. The organic carbon content of soils was found low (23.07\%), moderate (57.69\%), moderately high (17.30\%) and high (1.9\%), respectively. The data on calcium carbonate status are presented in Table 1. 
Table 1: Soil chemical properties

\begin{tabular}{|c|c|c|c|c|}
\hline Particulars & $\mathrm{pH}(1: 2.5)$ & $E C\left(d S m^{-1}\right)$ & Organic carbon (\%) & $\mathrm{CaCO}_{3}(\%)$ \\
\hline Mean & 8.29 & 0.39 & 0.50 & 8.97 \\
\hline Range & $7.78-8.73$ & $0.17-1.33$ & $0.21-0.82$ & $5.25-15.75$ \\
\hline \multirow{5}{*}{ Category } & & & Low $(23.07 \%)$ & Medium (83.65\%) \\
\hline & Slightly alkaline (6.73\%) & Normal (96.15\%) & Moderate (57.69 \%) & High (14.42\%) \\
\hline & \multirow{3}{*}{$\begin{array}{c}\text { Moderately alkaline } \\
(93.27 \%)\end{array}$} & \multirow{3}{*}{ Harmful (3.84\%) } & Moderately high & \multirow{3}{*}{ Harmful (0.96\%) } \\
\hline & & & $(17.30 \%)$ & \\
\hline & & & High (1.9 \%) & \\
\hline $\mathrm{SD} \pm$ & 0.17 & 0.19 & 0.13 & 1.86 \\
\hline
\end{tabular}

The calcium carbonate content in soils of the Sugar factory area was ranged from 5.25 to $15.75 \%$ with an average of $8.97 \%$. Among the 104 soil samples collected, $83.65 \%$ samples were found in medium category and $14.42 \%$, in high category and $0.96 \%$ are harmful category of calcium carbonate.

The soil available nitrogen of soils is presented in Table 2. The available nitrogen in soils of Sugar Factory area was ranged from 137.98 to $310.46 \mathrm{~kg} \mathrm{ha}^{-1}$ with an average of $229.62 \mathrm{~kg} \mathrm{ha}^{-1}$. The data on soil available phosphorus status are presented in Table 2 . The available phosphorus in soils was ranged from 6.37 to $27.12 \mathrm{~kg}$ ha ${ }^{1}$ with an average of $14.76 \mathrm{~kg} \mathrm{ha}^{-1}$. The data on available potassium status in soils are presented in Table 2 . The available potassium in soils was ranged from 257.60 to $763.20 \mathrm{~kg} \mathrm{ha}^{-1}$ with an average of $468.62 \mathrm{~kg} \mathrm{ha}^{-1}$.

Table 2: Soil available nitrogen, phosphorus and potassium status

\begin{tabular}{|c|c|c|c|}
\hline \multirow{2}{*}{ Particulars } & \multicolumn{3}{|c|}{ Soil available nutrients $\left(\mathrm{kg} \mathrm{ha}^{-1}\right)$} \\
\hline & $\mathbf{N}$ & $\mathbf{P}$ & $\mathbf{K}$ \\
\hline Mean & 229.62 & 14.76 & 468.62 \\
\hline \multirow[t]{4}{*}{ Range } & 137.98-310.46 & $6.37-27.12$ & $257.60-763.20$ \\
\hline & Very low (0.96\%) & Very low (0.96\%) & High (9.96\%) \\
\hline & & Low (44.23\%) & \\
\hline & Low $(87.5 \%)$ & Moderate (47.11\%) & Very High $(90.38 \%)$ \\
\hline Category & Moderate (11.53\%) & Moderately high (7.69\%) & \\
\hline $\mathrm{SD} \pm$ & 35.14 & 4.18 & 115.26 \\
\hline
\end{tabular}

The data on soil available boron are presented in Table 3. The available boron in soils ranged from 0.05 to $0.40 \mathrm{mg}$ $\mathrm{kg}^{-1}$ with an average of $0.26 \mathrm{mg} \mathrm{kg}^{-1}$. The critical limit of boron in soil was $0.5 \mathrm{mg} \mathrm{kg}^{-1}$.

Table 3: Soil available boron status

\begin{tabular}{cc}
\hline Particular & Available Boron $\left(\mathrm{mg} \mathrm{kg}^{-\mathbf{1}}\right)$ \\
\hline Mean & 0.26 \\
Range & $0.05-0.40$ \\
Category & Deficient (100\%) \\
SD \pm & 0.07 \\
\hline
\end{tabular}

The DTPA iron values of soils are presented in Table 4. The available iron content in soils was ranged from 2.00 to $6.06 \mathrm{mg} \mathrm{kg}^{-1}$ with an average of $4.17 \mathrm{mg} \mathrm{kg}^{-1}$. The available manganese of soils is presented in Table 4 . The available manganese in soils was ranged from 1.22 to $3.87 \mathrm{mg} \mathrm{kg}^{-1}$ with an average of $3.10 \mathrm{mg} \mathrm{kg}^{-1}$. The critical limit of available $\mathrm{Mn}$ in the soil is $2.0 \mathrm{mg} \mathrm{kg}^{-1}$. The data on the available zinc status of soils are presented in Table 4. The available zinc in soils was ranged from 0.24 to 1.86 $\mathrm{mg} \mathrm{kg}^{-1}$ with an average of $0.63 \mathrm{mg} \mathrm{kg}^{-1}$. The critical limit of $\mathrm{Zn}$ in the soil is $0.6 \mathrm{mg} \mathrm{kg}^{-1}$. The values of soil available copper are reported in Table 4. 
Table 4: DTPA micronutrients in soils

\begin{tabular}{ccccc}
\hline \multirow{2}{*}{ Particular } & \multicolumn{4}{c}{ DTPA micronutrients $\left(\mathbf{m g ~ k}^{-1}\right)$} \\
\cline { 2 - 5 } & $\mathbf{F e}$ & $\mathbf{M n}$ & $\mathbf{Z n}$ & $\mathbf{C u}$ \\
\hline Mean & 4.17 & 3.10 & 0.63 & 2.57 \\
Range & $2.00-6.06$ & $1.22-3.87$ & $0.24-1.86$ & $1.09-4.42$ \\
& Sufficient (30.76\%) & Sufficient (97.11\%) & Sufficient (34.62\%) & Sufficient \\
Category & Deficient (69.23\%) & Deficient (2.88\%) & Deficient (65.38\%) & $(100 \%)$ \\
& 0.94 & 0.54 & 0.30 & 0.69 \\
SD & & &
\end{tabular}

The available copper in soils was ranged from 1.09 to $4.42 \mathrm{mg} \mathrm{kg}^{-1}$ with an average value of $2.57 \mathrm{mg} \mathrm{kg}^{-1}$. The critical limit of $\mathrm{Cu}$ in the soil is $0.2 \mathrm{mg} \mathrm{k}^{-1}$. Based on Parker's fertility index the available N, P and $\mathrm{K}$ status in soil are categorized (Table 5 ) and it was observed that the available nitrogen was 1.11 (low), phosphorus 1.54 (medium) and potassium 3.0 (high), respectively.

Table 5: Parker's soil fertility status in the jurisdiction of sugar factory

\begin{tabular}{cccc}
\hline \multirow{2}{*}{ Ratings } & \multicolumn{3}{c}{ Available nutrients } \\
\cline { 2 - 4 } & $\mathbf{N}$ & $\mathbf{P}$ & $\mathbf{K}$ \\
\hline Parker Index & 1.11 & 1.54 & 3.00 \\
Category & Low & Medium & High \\
\hline
\end{tabular}

\section{DISCUSSION}

The moderately alkaline reactions of soil sample might be due to deep to medium black soils formed from basic parent material and being under irrigation longer time may have induced salinity by excesses irrigation leads to the alkaline condition ${ }^{[3,11]}$

The electric conductivity values of 104 samples out of that 100 i.e. (96.15\%) samples have normal EC which are normal in total soluble salt content and suitable for healthy plant growth, while 4 samples $(3.84 \%)$ have harmful EC that could affect the seed germination. The cultivated area from the sugar factory is naturally sloppy have a natural drain is a cause for observed $96.15 \%$ of soils as normal soil for salt content but some places water get stagnated due to poor drainage condition so it increases soluble salt content of that soil ${ }^{[12-15]}$.

The highest Organic carbon was $0.82 \%\left(19^{\circ} 52^{\prime} .758^{\prime \prime} \mathrm{N}\right.$ $\left.74^{\circ} 21^{\prime} .701^{\prime \prime} \mathrm{E}\right)$ and the lowest was $0.21 \%\left(19^{\circ} 54^{\prime} .616^{\prime \prime} \mathrm{N}\right.$ $74^{\circ} 22^{\prime} .204^{\prime \prime} \mathrm{E}$ ) as presented in Table 1 . The soils with moderate to low organic carbon content might be due to the content of soluble salts degrade the organic matter $[3,11,12,20]$.
The highest soil $\mathrm{CaCO}_{3}$ was $15.75 \%\left(19^{\circ} 51^{\prime} .734^{\prime \prime} \mathrm{N}\right.$ $\left.74^{\circ} 19^{\prime} .923^{\prime \prime} \mathrm{E}\right)$ and the lowest was $5.25 \%\left(19^{\circ} 53^{\prime} .451^{\prime \prime} \mathrm{N}\right.$ $\left.74^{\circ} 21^{\prime} .791^{\prime \prime} \mathrm{E}\right)$ as presented in Table 1 . It was well documented in the literature that calcareousness is common in soils of arid and semi-arid climate particularly in Vertisols (Black deep soils) due to precipitation of carbonates and bicarbonates. A similar trend of $\mathrm{CaCO}_{3}$ content was reported in soils of $\mathrm{C} B$ Block, Central Campus, M.P.K.V, Rahuri ${ }^{[16-19]}$.

The highest soil available status of nitrogen observed was $310.46 \mathrm{~kg} \mathrm{ha}^{-1}\left(19^{\circ} 51^{\prime} .923^{\prime \prime} \mathrm{N}-74^{\circ} 19^{\prime} .091^{\prime \prime} \mathrm{E}\right)$ and the lowest was $137.98 \mathrm{~kg} \mathrm{ha}^{-1}\left(19^{\circ} 51^{\prime} .734^{\prime \prime} \mathrm{N}-74^{\circ} 19^{\prime} .923^{\prime \prime} \mathrm{E}\right)$ as presented in Table 2 . Soil samples collected were categorized as very low (0.96\%), low (87.50\%) and moderate (11.53\%), which indicated the majority of soils, are low in soil available nitrogen content. It was well established that organic carbon has a positive correlation with available nitrogen. The data reported on organic carbon content and soil available nitrogen in study area soils confirm the observations of organic carbon and soil available nitrogen ${ }^{[20-22]}$.

The highest available phosphorus was $27.12 \mathrm{~kg} \mathrm{ha}^{-1}$ $\left(19^{\circ} 53^{\prime} .455^{\prime \prime} \mathrm{N}-74^{\circ} 21^{\prime} .756^{\prime \prime} \mathrm{E}\right)$ and the lowest was $6.37 \mathrm{~kg}$ $\mathrm{ha}^{-1}\left(19^{\circ} 51^{\prime} 764^{\prime \prime} \mathrm{N}-74^{\circ} 20^{\prime} .130^{\prime \prime} \mathrm{E}\right)$ as presented in Table2. Among the 104 soil samples collected, $0.96 \%$ in very low, $44.23 \%$ in low, $46.15 \%$ in moderate and7.69\% in moderately high categories was observed. The low status of available phosphorus in $44.23 \%$ of soils might be due to their alkaline condition and high content of $\mathrm{CaCO}_{3}$ in the soil which degrade the organic matter as well as transform the phosphorus to tricalcium phosphate and reduced the availability in soils ${ }^{[20,23-26]}$.

The highest available potassium was $763.20 \mathrm{~kg} \mathrm{ha}^{-1}$ $\left(19^{\circ} 54^{\prime} .268^{\prime \prime} \mathrm{N}-74^{\circ} 21^{\prime} .010^{\prime \prime} \mathrm{E}\right)$ and the lowest was 257.60 $\mathrm{kg} \mathrm{ha}^{-1}\left(19^{\circ} 52^{\prime} .414^{\prime \prime} \mathrm{N}-74^{\circ} 20^{\prime} .918^{\prime \prime} \mathrm{E}\right)$ as presented in table 2. Among the samples collected, $9.62 \%$ soils are high, and $90.38 \%$ samples are in the very high category. In 
general, the available $\mathrm{K}$ status of soils were very high in status, which could be attributed to the dissolution and diffusion process of potassium from internal crystal lattice of silicate clay minerals and might be due to also high clay content and montmorillonite clay minerals in soils ${ }^{[3,21-27]}$.

The soil available boron was numerically higher $0.40 \mathrm{mg}$ $\mathrm{kg}^{-1}\left(19^{\circ} 53^{\prime} .455^{\prime \prime} \mathrm{N}-74^{\circ} 21^{\prime} .756^{\prime \prime} \mathrm{E}\right)$ and the lowest was 0.05 $\mathrm{mg} \mathrm{kg}{ }^{-1}\left(19^{\circ} 54^{\prime} .585^{\prime \prime} \mathrm{N}-74^{\circ} 22^{\prime} .012^{\prime \prime E}\right)$ as presented in table 3 . In general, the available boron status in soils were $100 \%$ soil samples deficient in status, which might be due to the presence of a higher amount of $\mathrm{CaCO}_{3}$ in the soils ${ }^{[27]}$.

The highest available iron content was $6.06 \mathrm{mg} \mathrm{kg}$ ${ }^{1}\left(17^{\circ} 45^{\prime} .984^{\prime \prime} \mathrm{N}-74^{\circ} 50^{\prime} .208^{\prime \prime} \mathrm{E}\right)$ and the lowest was 2.00 $\mathrm{mg} \mathrm{kg}{ }^{-1}\left(17^{\circ} 46^{\prime} .837^{\prime \prime} \mathrm{N}-74^{\circ} 50^{\prime} .159^{\prime \prime} \mathrm{E}\right)$ as presented in table 4. The critical limit of iron in soil was $4.5 \mathrm{mg} \mathrm{kg}^{-1}$. In general, the available Fe content in soils was sufficient (30.76\%). This deficiency might be due to excess $\mathrm{CaCO}_{3}$ content and alkaline $\mathrm{pH}$ of soil ${ }^{[5,28-31]}$.

The highest available manganese was $3.87 \mathrm{mg} \mathrm{kg}^{-1}$ (17 $\left.47^{\prime} .009^{\prime \prime} \mathrm{N}-74^{\circ} 50^{\prime} .099^{\prime \prime} \mathrm{E}\right)$ and the lowest $1.22 \mathrm{mg} \mathrm{kg}^{-1}$ $\left(17^{\circ} 47^{\prime} .615^{\prime \prime}-74^{\circ} 50^{\prime} .408^{\prime \prime} \mathrm{E}\right)$ presented in Table 4. The $(97.11 \%)$ soil samples were sufficient while only $2.88 \%$ of soil samples were deficient in available manganese based on the critical limit. The sufficiency of available $\mathrm{Mn}$ in soils might be due to moderate organic matter content and also due to a sufficient amount of carbonates and bicarbonates ${ }^{[11,32,33]}$.

The highest available zinc was $1.86 \mathrm{mg} \mathrm{kg}^{-1}\left(17^{\circ} 47.009 \mathrm{~N}-\right.$ $\left.74^{\circ} 50.099 \mathrm{E}\right)$ and the lowest was $0.24 \mathrm{mg} \mathrm{kg}{ }^{-1}$ $\left(17^{\circ} 44.043 \mathrm{~N}-74^{\circ} 49.988 \mathrm{E}\right)$ presented in Table 4 . The $65.38 \%$ soil samples were in the deficient category and $34.62 \%$ soil sample were sufficient category, as the critical limit of available zinc is $0.6 \mathrm{mg} \mathrm{kg}^{-1}$. Most of the soils found deficient in available $\mathrm{Zn}$ is might be due to intensive cultivation and deep black soils are deficient in Zinc. The farmer in this region did not apply zinc and less amount of organic manure application ${ }^{[2,28,34]}$.

The highest available copper was $4.42 \mathrm{mg} \mathrm{kg} \mathrm{kg}^{-1}$ $\left(17^{\circ} 47.601 \mathrm{~N}-74^{\circ} 50.077 \mathrm{E}\right)$ and the lowest was $1.09 \mathrm{mg} \mathrm{kg}$ ${ }^{1}\left(17^{\circ} 46.381 \mathrm{~N}-74^{\circ} 51.307 \mathrm{E}\right)$ presented in Table 4 . All the 104 soil samples collected from the jurisdiction of sugar factory were $100 \%$ sufficient in available copper, as the critical limit of available copper is $0.2 \mathrm{mg} \mathrm{kg}^{-1}$. This might be because of the addition of organic matter through trash management and the use of copper-containing pesticides ${ }^{[35,36]}$.

\section{CONCLUSIONS}

The soils in the jurisdiction of sugar factory were moderately alkaline in reaction. The micronutrients viz., $\mathrm{B}, \mathrm{Fe}, \mathrm{Mn}$ and $\mathrm{Zn}$ were deficient to the extent of 100, 69.23, 2.88 and 65.38\%, respectively. The Parker's soil fertility index in the jurisdiction of sugar factory was low in available $N$ (1.11), medium in available $P(1.54)$ and high in available $\mathrm{K}$ (3.00).

The application of fertilizers should be as per soil test. The jurisdiction of sugar factory needs to increase the nitrogenous fertilizers dose by 50 per cent as per recommended dose of fertilizer. It is also advocated to apply the micronutrients viz., B, Fe, Mn and $\mathrm{Zn}$ with FYM.

\section{CONTRIBUTION OF AUTHORS}

Research concept- Dr. A. L. Pharande

Research design- Dr. S. R. Shelke

Supervision- Dr. S. R. Shelke

Materials-Mr. P.A. Gayke

Data collection- Mr. P. A. Gayke

Data analysis and Interpretation- Dr. S.R. Shelke

Literature search- Mr. P. A. Gayke

Writing article- Dr. S. R. Shelke

Critical review- A. L. Pharande

Article editing- Dr. S.R. Shelke

Final approval- A. L. Pharande

\section{REFERENCES}

[1] Challa O, Vadivelu S, Sehgal JT. Soils of Maharashtra for optimizing land use. NBSS Pub, 54 (soils of India series). NBSS and Land Use Planning Nagpur, 1995; pp.112.

[2] Arora S, Chahal DS. Forms of boron in alkaline alluvial soils in relation to soils properties and their contribution to available and total boron pool. Comm. Soil Sci. PI. Anal., 2014; 45(17): 2247-57.

[3] Gosavi NI. GPS-GIS based soil fertility maps of Shirpur Tehsil of Dhule District (M.S.). Student of M.Sc. (Agri) Department of Soil Science and Agril. Chemistry, College of Agriculture, Dhule. Thesis submitted to Mahatma Phule Krishi Vidyapeeth, Rahuri, 2015.

[4] Jackson ML. Soil chemical analysis, prentice hall of India. Private limited New Delhi, 1973; pp. 498.

[5] Nelson DW, Sommer LE. Total carbon, organic carbon and organic matter. Methods of Soil Analysis, 
Part 2. Chemical and Microbiological Properties, $2^{\text {nd }}$ Edition. ASA-SSSA, Madison, 1982; pp. 595-79.

[6] Piper CS. Soil and plant analysis. Hans Publisher, Bombay, 1966.

[7] Subbiah BV, Asija GL. A rapid procedure for the estimation of available nitrogen in soils. Cur Sci., 1956; 25: 259-60.

[8] Watanabe FS, Olsen SR. Test of ascorbic acid methods for phosphorus in water and sodium bicarbonate extract of soil. Proceedings of Soil Science Society of America, 1965; 21: 677-78.

[9] Lindsay WL, Norvell WA. Development of DTPA soil test of Fe, Mn, Zn and Cu. Soil Sci Soc Am. J., 1978; 42: 421-28.

[10]Bingham FT. Boron. In: Page, A.L., Ed., Methods of soil Analysis Part-2 Chemical and Mineralogical Properties. Am Soc Agron., 1982; pp. 431-48.

[11]Meena S. Studies on physical and chemical properties of salt affected soils of central research farm, Mahatma Phule Krishi Vidyapeeth, Rahuri. M.Sc. (Agri.) Thesis submitted to the Mahatma Phule Krishi Vidyapeeth, Rahuri (Maharashtra), 2009.

[12]Padole VR, Mahajan SB. Status and release behavior of potassium in swell-shrink soils of Vidarbha. Maharashtra. J Mah Agril Uni., 2003; 28: 3-7.

[13]Shinde LV, Phalke GB. Chemical composition of soil from Godavari basin of Beed (M.S.) India. Bio Disc., 2014; 5(1): 15-18.

[14]Nalawade AS. GIS based soil fertility map of Agriculture Research Station, Savalevihir Farm, TehsilKopergaon. M.Sc. (Agri.) Thesis submitted to the Mahatma Phule Krishi Vidyapeeth, Rahuri (M.S.), 2013.

[15]Mishra A, Pattnaik T, Das D, Das M. Soil fertility maps preparation by using GPS and GIS Dhenkanal district of Odisha. Int J PI Soil Sci., 2014; 3: 986-94.

[16]Durgude AG. Morphology, characterization, classification and mapping of salt affected soils of Central Campus, Research Farms, Mahatma PhuleKrishiVidyapeeth, Rahuri. Ph.D. Thesis submitted to M.P.K.V, Rahuri (M.S.), 1995.

[17]Medhe SR, Takankha VG, Salve AN. Correlation of chemical properties, secondary nutrients micronutrients anions from the soils of Chakur Tehsil of Latur district of Maharashtra. Tren. Life Sci. An Int Peer Rev J., 2012; 1: 34-40.
[18]Chaudhari RD, Kadu PP. Assessment of fertility status of the soils of Dhuletehsil of Dhule district. Paper presented in state level seminar on soil health enhancement for food and environmental security, organized by PCISSS, at Marathwada Agricultural University Parbhani, 2007; 12 \& 13: 2.

[19]Kanwar JS. Address by the guest of honor, $69^{\text {th }}$ annual convention of the Indian Society of Soil Science held at the Acharya N.G. Ranga Agricultural University (ANGRAU) Hydrabad. J Ind Soc Soil Sci., 2004; 52: 295-296.

[20]Pandey SP, Singh RS, Mishra SK. Availability of phosphorus and sulphur in Inceptisols of central Uttar Pradesh. J Ind Soc Soil Sci., 2000; 48: 118-121.

[21]Padmavathi T, Muthukrishnan R, Mani S, Sivasamy R. Assessment of soil physico-chemical properties and macronutrients status in Coimbatore district of Tamil Nadu using GIS techniques. Trends Biosci., 2014; 7(19): 2874-81.

[22]Ravikumar P, Somashekar RK. Spatial distribution of macronutrients in soils of Markandeya river basin, Belgaum (d), Karnataka(s), India. Proc. Int Acad Ecol Environ Sci., 2014; 4(2): 81-94.

[23] Kumar A, Mishra VN, Srivastava LK. Evaluation of soil fertility status of available N, P and K in Inseptisol of Raipur district of Chhattisgarh. Int J Interdiscip Multidiscip Stu., 2015; 2(6): 98-104.

[24]Nalina CN, et al. Soil nutrient status mapping of Nagenahalli micro-watershed under Eastern Dry Zone of Karnataka by remote sensing, detailed soil survey, India, 2016.

[25]Shinde YR, Indulkar BS, Waghmare MS. Soil nutrient index of available N, $P$ and $K$ in soils from Udgir Tehsil of Latur district (M.S). Bul Pure Appl Sci., 2014; 33: 21-26.

[26]Shirgave P, Ramteke A. Physico-chemical status of fertile soil around Arjunnagar, district Kohlapur, Maharashtra. Int J Chem Stud., 2015; 3(2): 98-101.

[27]Sharma BD, Katyal JK. Water soluble boron in benchmark soils in India and their relationship with soil properties. J Ind Soc Rem Sens., 2006; 54(1): 5758.

[28]Kumar A, Mishra VN, Srivastav LK, Banwasi R. Evaluation of soil fertility status of available major nutrients ( $N, P \& K$ ) and micro nutrients ( $\mathrm{Fe}, \mathrm{Mn}, \mathrm{Cu}$ \& $\mathrm{Zn}$ ) in Vertisol of Kabeerdham district of 
Chhattisgarh, India. Int Multidiscip Res J., 2014; 1(10): 72-79.

[29]Patil KD, Meisheri MB. Minerological studies and DTPA extractable $\mathrm{Zn}, \mathrm{Cu}, \mathrm{Mn}$ and $\mathrm{Fe}$ in representative soils of Konkan regions. J Mah Agric Univ., 2004; 29: 04-08.

[30]Nadeem YN, Majeed T, Ahmad N, Ibrahim M, et al. Micronutrients status of Mango orchards of Multan and Lodhran dist. J Agric Res., 2009; 47(4): 413-21.

[31]Nagendran AA. Vertical distribution of DTPAextractable micronutrients in soils of Cumbum valley, Tamil Nadu. Agric Sci Digest., 2010; 30: 79-84.

[32] Mandavgade RR, Waikar SL, Dhamak AL, Patil VD. Evaluation of micronutrient status of soils and their relation with some chemical properties of soils of northern tehsils (Jintur, Selu and Pathri) of Parbhani district. IOSR J Agric Vet Sci., 2015; 8: 38-41.
[33]Minakshi NS, Nayyar VK, Sharma PK, Sood AK. Spatial distribution of micronutrients in soils of Patiala District. J Ind Soc Soil Sci., 2005; 53: 324-29.

[34]Kharche VK, Patil JD, Bulbule AV. Micronutrient status of soils of Nashik district, Maharashtra. National Seminar on Development in Soil Science, 2001; pp. 161.

[35] Katariya P. Characterization and classification of soils of water management project, Mahatma Phule Krishi Vidyapeeth, Rahuri. M.Sc. (Agri) Thesis, Mahatma Phule Krishi Vidyapeeth, Rahuri (Maharashtra), 2011.

[36]Baruah R, Thiyageshwari S, Mani S, Velu V, Stalin P. Distribution of available iron, manganese, zinc, copper and boron in soils of Cuddalore district of Tamil Nadu. J Indian Soc Soil Sci., 2014; 62(3): 28892.

\section{Open Access Policy:}

Authors/Contributors are responsible for originality, contents, correct references, and ethical issues. SSR-IIJLS publishes all articles under Creative Commons Attribution- Non-Commercial 4.0 International License (CC BY-NC). https://creativecommons.org/licenses/by-nc/4.0/legalcode (c) (i) (8) 